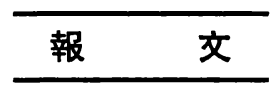

\title{
高血圧予防教室に関する実践的研究
}

杉浦喜美子, 田沼順子, 猪俣保子, 中島洋子, 樋口京子 松田美智子, 大久保妙子, 唐島 美 鶴, 土屋真紀子, 森 桂子 小西邦子, 関谷和恵, 大田紀子, 立松道子, 石川順子

白石京子, 渡辺純子, 豊川裕之*, 小野田博一*

横浜市衛生局保健所, *東京大学医学部保健学科疫学教室

\section{Improvements in Dietary Life of Attendants in Classes for Prevention of Hypertension in Yokohama City}

\author{
Kimiko Sugiura, Junko Tanuma, Yasuko Inomata, Yoko Nakajima, Kyoko Higuchi, \\ Michiko Matsuda, Taeko Ohkubo, Mitsuru Karashima, Makiko Tsuchiya, Keiko Mori, \\ Kuniko Konishi, Kazue Sekiya, Noriko Ohta, Michiko Tatematsu, Junko Ishikawa, \\ Kyoko Shiraishi, Junko Watanabe, Hiroyuki Toyokawa* and Hirokazu Onoda* \\ The Health Center; Bureau of Hygiene; Government of Yokohama City, \\ *Department of Epidemiology; School of Health Sciences; University of Tokyo
}

Since 1977, volunteer classes for people wishing to study about prevention of hypertensions have been held in Health Centers in Yokohama City. After 1982, the classes began to be held on regular basis. Dietitians were not necessarily sure of the curricula for the classes because of their inability to assess the effective behavioral improvements in the attendants. Authors tried to improve this situation by jointly preparing improved curricula based on clear identification of objectives, resources, strategy, time table and pre-test and post-test evaluations in accordance with the health education method promoted by WHO.

The study was conducted on 80 attendants during the period from August, 1979 to March, 1980 in 7 Health Centers. They were given follow-ups in respect of all the items described in two short questionnaires and records of two meals (taken on two days). The curriculum adopted is oriented toward changing the food pattern in an effort to prevent hypertension.

Authors believe that they have found a possibility of improving the dietary patterns of clients despite many difficulties in the behavioral changes.

Jpn. J. Nutr., 41 ( 4 ) 209 216 (1983)

\section{はじめに}

横浜市は, 昭和40年頃より成人病予防対策の一環として循環器検診を実施し1), 疾病の早期発見, 早期 治 療, および予防思想普及に努め, かつ検診後の生活指導と栄養指道を行ってきた。しかし, 著者らは行政的立 場からこの対策事業に参加して，栄養指導が生活の中に踏み込えで生活習慣の改善の効果をあげるに至らなか ったことを反省している。

Key words : class for prevention of hypertension, food intake survey, milk, processed food of rice, pickled vegetables, soy sause

高血圧予防教室, 食物摄取調査, 牛乳, 米加工品, 漬け物, しょ5ゆ 
表 1 生活・身体状況調査票 (高血圧予防教室)

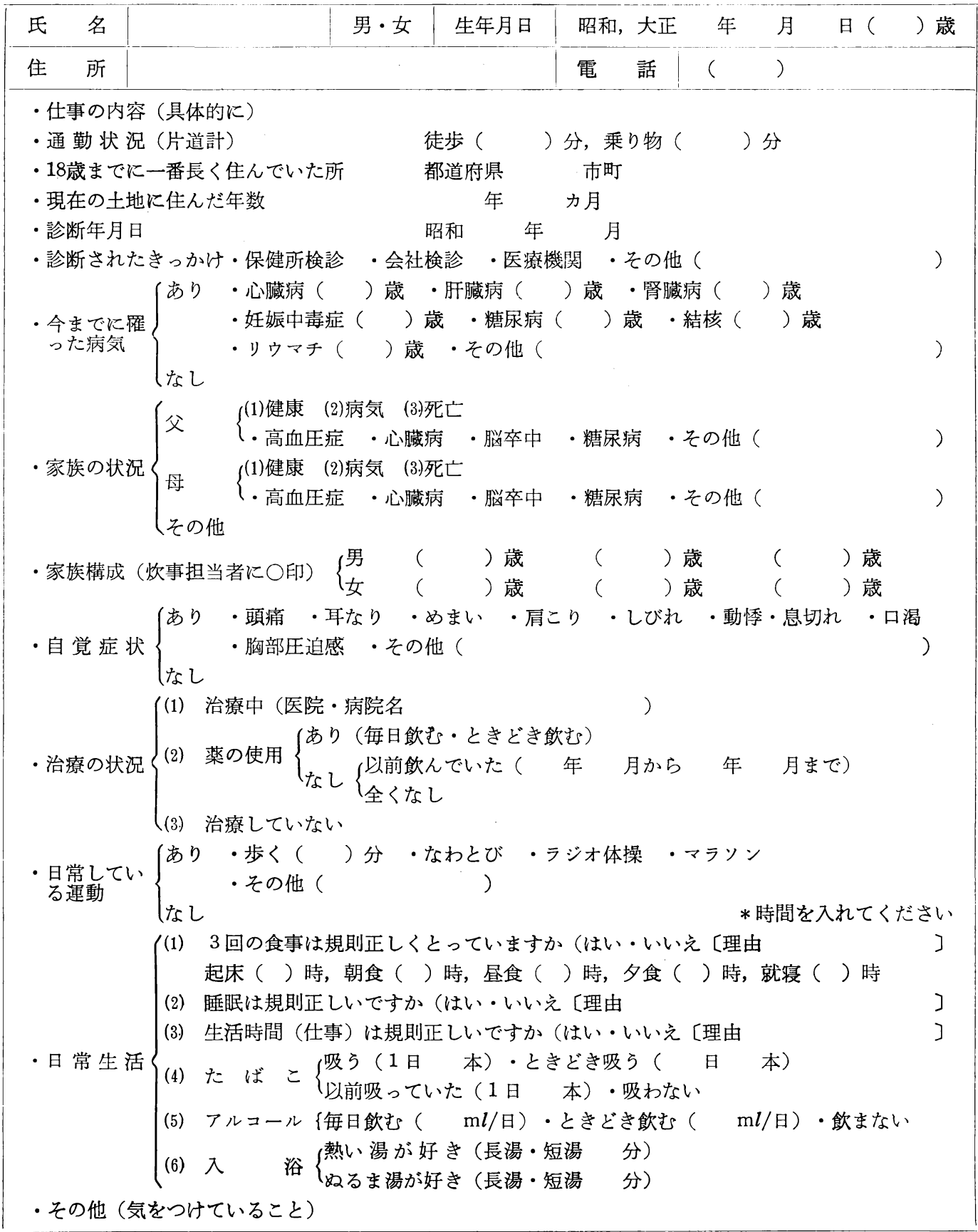

一方, 生活環境のほうも急激に变化しており ${ }^{2)}$, 栄養指導効果の不徹底の 1 つして, 保健所の栄養指導法 がその変化に十分に対処できなかったことが考えられる。

環境の急激な変化ばかりではなく，高秢化社会への推移といわれる対象者の変化もあっで)，担当地域の社 会的ニーズの变化は複雑な様相を呈している。このような実態認識に立って, 著者らは“高血圧予防教室”を 
保健所関連職種との協力のもとに総合的カリキュラムを用意して，昭和52年より実施した。

本研究では, 特に効果判定に力点をおいて実態分析したことを報告する。なお，この意図は横浜市の正式事 業「横浜市高血圧教室等要領」4) (昭和57年度施行)として軌道にのった。

\section{調 查 概 要}

\section{1. 実施保健所}

横浜市鶴見第二, 南, 港南, 保土ヶ谷, 磯子, 緑, 戸塚の各保健所。

\section{2. 調查実施期間}

昭和 54 年 8 月から昭和 55 年 3 月までの 8 カ月間にわたって，各保健所ごとに 1 コースを実施した。

3. 調查内容と方法

1）生活状況・身体状況調査は, 質問票（表 1）を自己記入で実施した。

2）食物攝取状況調査は国民栄養調査（厚生省）の食物捸取状況調査票に準じて作成した調查票を用いて, 個人の食事内容を, 料理名, 食材料名, 使用 量 (概量), 間食食品名などを自己記入法で 収集した。な拉，前後 2 回これを実施したが， 第 1 回調査は受講第 1 日に調査票を手渡し, 受講第 2 日に回収した。第 2 回調査は受講第 3 日に同じ形式の調査票を手渡し, 受講第 4 日（最終日）に回収した。調査期間は 2 回と も日曜・祭日を除く連続 2 日間とした。なお, 回収に当たってはフード・モデルを利用しな がら担当栄養士が記録事項と数量を確認した (表 2 )。

\section{対}

\section{象}

本研究の対象である高血圧予防教室受講者 は, 保健所が実施する循環器検診と一般健 康相談日に受診し, 高 血圧・境界域 (WHO 基準による) と判定された本人および市広 報による応募者である。対象人数は受講者の 中で食物摄取状況調查の 2 回分の調查票がそ ろっている 80 人（男子: 12 人，女子：68人） である。

対象者の年齢構成では，40歳代が最も多く， 平均年歯㭷子 52.8 歳, 女子 49.2 歳である (表 3 )。職業は家事従事者が最も高率である (表 4 )。このように, 保健所が実施する講習

表 2 高血圧予防教室プログラム概要

\begin{tabular}{|c|c|c|}
\hline 回数 & 内 & 担 当 者 \\
\hline 1 & $\begin{array}{l}\text { オリエンテーション } \\
\text { 計測, 検査（身長, 体重, } \\
\text { 肥厚, 血圧, 尿, } \\
\text { 血液検查) }\end{array}$ & $\begin{array}{l}\text { 所 長 } \\
\text { 医 師, 保健婦, } \\
\text { 看護婦, 栄養士 } \\
\text { （雇い上げ栄養士 } \\
\text { を含む） } \\
\text { 臨床検查技師 } \\
\text { 衛生教育担当者 } \\
\text { 事 務 }\end{array}$ \\
\hline 2 & $\begin{array}{l}\text { 検査結果の説明 } \\
\text { 講話「食事について」その } 1 \\
\\
\text { 調理実演 ; } 1 \text { 日分の献立 }\end{array}$ & $\begin{array}{l}\text { 医 師 } \\
\text { 栄養士 (雇い上げ } \\
\text { 栄養士含む) } \\
\text { 事 務 }\end{array}$ \\
\hline 3 & $\begin{array}{l}\text { 講話「運動について」 } \\
\text { 「生活について」 } \\
\text { 「食事について」その } 2 \\
\text { 調理実演 ; 薄味の工夫 }\end{array}$ & $\begin{array}{l}\text { 外来講師 } \\
\text { 保健婦 } \\
\text { 栄養士（雇い上げ } \\
\text { 栄養士含む） } \\
\text { 事 務 }\end{array}$ \\
\hline 4 & $\begin{array}{l}\text { 食事調査結果に基づいた食 } \\
\text { 事の注意 } \\
\text { グループ別話し合い } \\
\text { フンケート (ポストテスト } \\
\quad \text { 含む) }\end{array}$ & $\begin{array}{l}\text { 所 長 } \\
\text { 医 師 } \\
\text { 保健婦 } \\
\text { 栄養士（雇い上 } \\
\text { げ栄養士含む） } \\
\text { 事 務 }\end{array}$ \\
\hline & 個別指導 & 栄養士, 保健婦 \\
\hline
\end{tabular}

注） 1 回半日単位とする。 
表 3 受講者の年齡構成 (人)

\begin{tabular}{ccc}
\hline 年齡 & 女子 & 男子 \\
\hline 20 歳代 & 1 & 0 \\
30 歳代 & 7 & 1 \\
40 歳代 & 29 & 6 \\
50 歳代 & 24 & 1 \\
60 歳代 & 7 & 2 \\
70 歳代 & 0 & 2 \\
\hline 合 計 & 68 & 12 \\
\hline
\end{tabular}

会の受講者として最もふつらにみられるものである。 なお，高血压ないし境界域といら判定をはじめて受 けた場所としては保健所検診が最も多い(図 1 )。 受療状海では受療している者を服薬群とし, 診察を 受けているが服薬していない者および非受療者を非 服薬群として，高血圧管理状況で 2 群に分けた。そ の結果, 受講者は服薬群 32 人 (40\%), 非服薬群 48 人 $(60 \%)$ である（図 2 )。なお，自覚症状では肩
表 4 受講者の職業分類

(人)

\begin{tabular}{|c|c|c|c|c|c|c|c|}
\hline & $\begin{array}{l}\text { 家 } \\
\text { 事 } \\
\text { 苻 } \\
\text { 事 } \\
\text { 者 }\end{array}$ & $\begin{array}{l}\text { 常 } \\
\text { 角 } \\
\text { 勤 } \\
\text { 労 } \\
\text { 者 }\end{array}$ & $\begin{array}{l}\text { パ } \\
1 \\
r\end{array}$ & $\begin{array}{l}\text { 自 } \\
\text { 営 } \\
\text { 業 }\end{array}$ & $\begin{array}{l}\text { そ } \\
\text { の } \\
\text { 他 }\end{array}$ & 無 & 合 \\
\hline 女子 & 63 & 0 & 3 & 1 & 1 & 0 & 68 \\
\hline 男子 & 0 & 6 & 0 & 2 & 1 & 3 & 12 \\
\hline
\end{tabular}

表 5 自覚症状

\begin{tabular}{|c|c|c|c|}
\hline な & \multicolumn{2}{|c|}{ ᄂ } & 9 人 $(11.3 \%)$ \\
\hline あ & \multicolumn{2}{|c|}{$り$} & 71 人 $(88.7 \%)$ \\
\hline \multirow[t]{9}{*}{ 内 訳 } & 頭 & 痛 & 19 人 $(26.8 \%)$ \\
\hline & 耳 & な & 10 人 $(14.1 \%)$ \\
\hline & め & ま & 12 人 $(16.9 \%)$ \\
\hline & 肩 & $こ$ & 43 人 $(60.6 \%)$ \\
\hline & & び表れ & 13 人 $(18.3 \%)$ \\
\hline & 動 & - 息切れ & 12 人 $(16.9 \%)$ \\
\hline & 胸? & 圧迫感 & 7 人 $(9.8 \%)$ \\
\hline & そ & の 他 & 31 人 $(43.7 \%)$ \\
\hline & 不 & 明 & 0 人 $(-)$ \\
\hline
\end{tabular}

こりを訴えるものが全体の60.6\%であるが，複数の症状を訴える者が多い（表 5 )。

肥満度については, 厚生省指導資料に示された身長別体重表による分類に従うと, 標準領域 41 人(51.3\%), やや肥満領域 21 人 (26.3\%), 肥満領域 12 人 (15.0\%), るいそう領域 5 人 (6.2\%) であった。

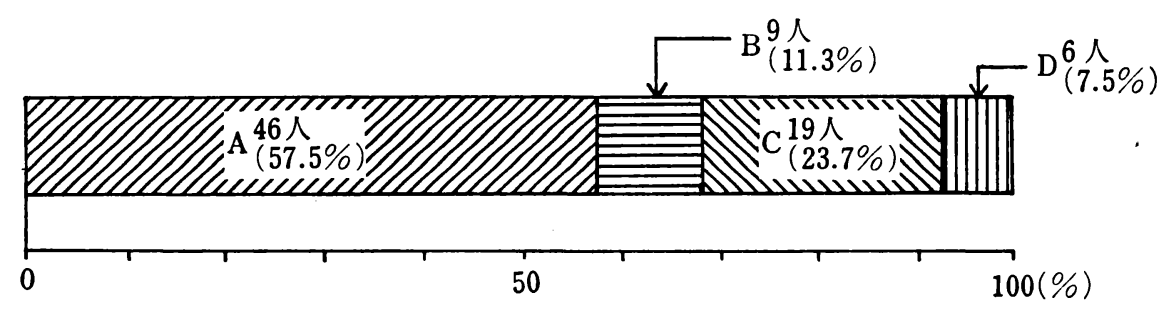

困 1 診断されたきっかけ
A : 保健所検診
$\mathrm{B}:$ 医療機関で受診
C : 事業所検診
$\mathrm{D}:$ その他

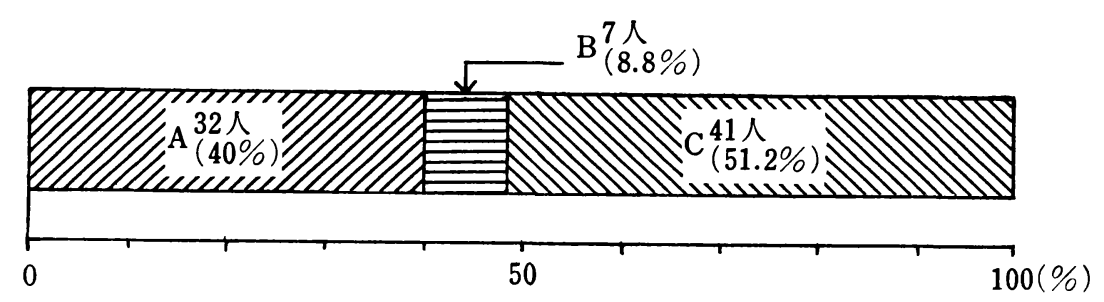

困 2 治療状況

$\mathrm{A}$ ：治療あり, 薬あり $\mathrm{B}$ ：治療あり, 薬なし $\mathrm{C}$ ：治療なし 
血圧值については高血圧領域 40人 (48.8\%), 境界領域 30 人 (37.5\%) で, 正常領域 9 人 (11.2\%) も含 まれた。

上述のように本対象は，保健所業務としてはいつも集まるごく普通の受講者である。

\section{高血圧予防教室のプログラム}

本教室で企画された標準プログラムは，1 1 月 4 回コースであり， 1 回の所要時間は 2 時間 30 分とした。各 保健所によって標準プログラムを一部変更して現物適用を行らことを認めたが，骨子は遵守された。

本研究は学術研究に徹するのではなく，業務適用を前提としたので以下の諸点を工夫した。

1）保健所内部の調整と社会的ニーズの尊重を重視した。

2）食物捸取状況調査だけは共通事項とした。そして，食事内容の自己秤量と記録および栄養士による確認 は全て教育的効果を意図したものである。

3）高血圧と循環器疾患を標的とする臨床検查の実施は，各保健所の取り組み方にまかせた。しかし，その 項目は全て保健所の検査機能を越えるものではなく, 検尿, 血清コレステロール, 血色素, 血圧, 心電戝検査 などであった。受講者はその検査值の説明をらけながら，基礎的な高血圧病態を理解し，その予防に関心をも つように工夫した。

4）栄養士の立場から，食物摂取状況が本教室を受講することによって，どの程度变化ないし改善されるか を知ることに重点をおいたので, 前後 2 回の食物摄取状況調查を組み入れた。

上述のような，4回，のべ10時間の教室によっては大きく改善することは期待できないものの，保健所業務 としては最も一般的な内容であるので, 本研究で改めてその効果判定を試みるために上記のプログラムを採用 した。

結 果

\section{1. 食品群別提取吾の増減}

食品を36食品群 (米, 米加工品, 小麦粉, パン, めん, 即席めん, 種実, いも, いも加工品, 砂楉, 菓子, 油・バター, マヨネーズ, 味噌, 大豆製品, その他の豆, 果実, 緑黄色野荣, その他の野菜, きのこ, 海藻, 漬け物, 生魚, 塩干魚, 魚加工品, 生肉, 肉加工品, 卵, 牛乳, 乳製品, しょうゆ, 塩, その他の調味料, 加 工食品，その他嫩好飲料，その他）に分類し，それぞれの 1 日当たり平均攝取量を各回ごとに集計した(表 6 )。

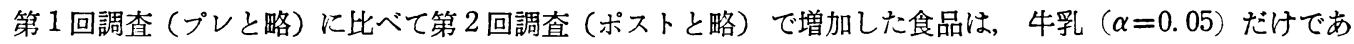
り，逆に，減少した食品は米加工品（ $\alpha=0.05 ）$ ，漬け物，しょらゆ $(\alpha=0.001)$ である。しかし，好ましい 方向に増加ないし減少したとはいえ, ここにあげた 4 食品群は単品として使用されたり, 意図的に隇らしたり 増やしたりしやすい食品ばかりであって，惣菜・料理として複雑な消費のされ方をされる食品や，米のように 食生活にしっかり根をおろしている食品ではなかった。このことは本教室のカリキュラム内容にも関係してい ることではないかと思われるが，受講前から既にマスコミュニケーションなどを通して知られていた知識に負 らところが大きく，本教室の指導効果によるものとは判断できない。

\section{2. 受療・服薬の有無と指型効果の関係}

高血压の治療を受けている人と受けていない人とでは，本教室の指導効果に差があるかどうかを検討するた めに, 服薬群と非服薬群の食物攝取状況を比較した。表 7 では, 第 1 回調查と, 第 2 回の調査食品別摂取量と 
その差（ポストの量ープレの量）および $t$ 值を示した。

服薬群では緑黄色野菜 $(\alpha=0.05)$ と加工食品 $(\alpha=0.001)$ が增加し, 清け物, しょうゆ（ともに $\alpha=0.05 ）$ が減少している。一方, 非服薬群では牛乳 $(\alpha=0.05)$ とその他の豆類 $(\alpha=0.05)$ が増加し, 漬 け物 $(\alpha=$ $0.01)$, しょうゆ $(\alpha=0.05)$, 加工食品 $(\alpha=0.05)$ が減少している。このことから, 非服薬群が服薬群より む好ましい変化をしたことにな る。したがって, 高血圧症状が服 薬しなければならないほど進行し ている人は, 軽症者よりも, この 教室では指導勃果があがらなかっ たと判断できる。しかしながら，

軽症者であっても栄養士としては 必ずしも満足できる成果があがっ たとは思えない。1 コース 4 回の 高血圧予防教室としてはこの成果 でもよいと思われるが，果たして 日常生活の中でこの変化 (改善) が定着しているかどうか疑わしい からである。

\section{考 \\ 察}

高血圧予防教室を実施するに当 たって，行政レベルの運営であっ ても, 教室の指導効果を客観的に 判定し, その評価と反省の上に立 ってその後のカリキュラム内容を 改善することがなくては, 現在進 行している生活環境の激しい変化 と高齢化社会に対処できなくなる と考えて本研究を実施した。ると より学術的に厳密な研究であるた めには，対象の選定や各保健所の 教室内容を完全に統一しなければ ならないことを認めるのにやぶさ かではないが，行政レベルの業務 ではそのよらな研究のための条件 設定は不可能であり，かつ容認さ れないであろう。しかし，現実に
表 6 第 1 回調査と第 2 回調査の揕取量とその比較

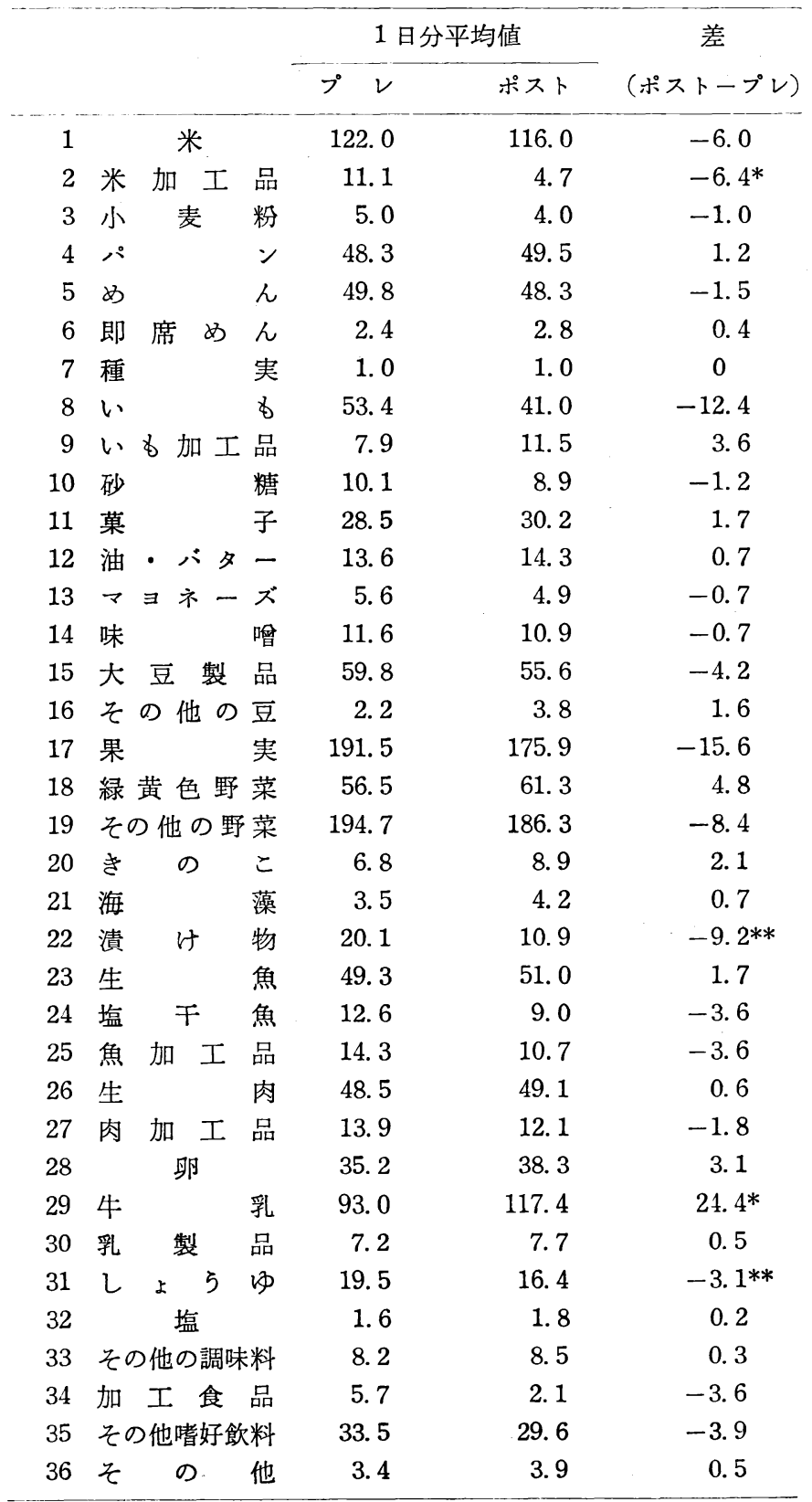

$*: p<0.05 \quad * *: p<0.001$

(14) 
は保健所業務の中でもできるかぎり客観的な検討が必要であるので，本研究ではありのままの対象について， 実務に沿った内容の高血圧予防教室を実施し，その成果について可能なかぎり客観的に分析・検討したもので ある。

表 7 治療状況別の食品摂取状況

\begin{tabular}{|c|c|c|c|c|c|c|c|c|c|c|}
\hline & \multirow{3}{*}{ 食 } & \multirow{3}{*}{ 名 } & \multicolumn{4}{|c|}{ 服 薬 あ り } & \multicolumn{2}{|r|}{ 服 薬 } & \multicolumn{2}{|l|}{ な し } \\
\hline & & & \multicolumn{2}{|c|}{$\begin{array}{l}2 \text { 日分の摄取量 } \\
\text { の平均値 (g) }\end{array}$} & \multirow{2}{*}{$\begin{array}{l}\text { 差美均值 } \\
\text { (ポスト } \\
\text {-プレ) }\end{array}$} & \multirow{2}{*}{$\begin{array}{l}\text { 差の平 } \\
\text { 均の } t \\
\text { 值 }\end{array}$} & \multicolumn{2}{|c|}{$\begin{array}{l}2 \text { 日分の找取量 } \\
\text { の平均做 }(\mathrm{g})\end{array}$} & \multirow{2}{*}{$\begin{array}{l}\text { 差 の } \\
\text { 平均値 } \\
\text { (ポスト } \\
\text { ープレ) }\end{array}$} & \multirow{2}{*}{$\begin{array}{l}\text { 差の平 } \\
\text { 均の } t \\
\text { 值 }\end{array}$} \\
\hline & & & プレ & ポスト & & & プレ & ポスト & & \\
\hline 1 & 米 & & 241.3 & 207.6 & -33.8 & -1.96 & 245.8 & 248.0 & 2.2 & 0.18 \\
\hline 2 & 米 加 工 & 品 & 13.8 & 2.5 & -11.3 & -1.48 & 27.8 & 14.1 & -13.8 & -1.70 \\
\hline 3 & 小 & 粉 & 10.3 & 5.3 & -4.9 & -1.75 & 9.8 & 9.5 & -0.2 & -0.08 \\
\hline 4 & パ & ン & 102.7 & 94.2 & -8.5 & -1.14 & 92.4 & 102.1 & 9.7 & 0.83 \\
\hline 5 & め & L & 108.4 & 142.5 & 34.1 & 1.15 & 93.5 & 65.8 & -27.8 & -1.39 \\
\hline 6 & 即 席 め & ん & 6.0 & 2.2 & -3.8 & -0.78 & 4. 0 & 7.9 & 3. 9 & 0.57 \\
\hline 7 & 種 & 実 & 1.1 & 2.1 & 1.0 & 1. 18 & 2.5 & 1.8 & -0.7 & -0.35 \\
\hline 8 & W & $\phi$ & 123.1 & 84.1 & -39.1 & -1.70 & 96.0 & 80.6 & -15.4 & -0.89 \\
\hline 9 & W \& 加 I & 品 & 24.9 & 22.3 & -2.7 & -0.32 & 9.5 & 23.4 & 14.0 & 1. 73 \\
\hline 10 & 砂 & 糖 & 22.4 & 17.8 & -4.6 & -1.45 & 18.8 & 17.6 & -1.2 & -0.54 \\
\hline 11 & 菓 & 子 & 41.3 & 38.7 & -2.6 & -0.22 & 67.2 & 74.8 & 7.5 & 0.44 \\
\hline 12 & 油・バタ. & - & 23.6 & 25.9 & 2.3 & 0.63 & 29.4 & 30.2 & 0.8 & 0.26 \\
\hline 13 & $\checkmark \exists ネ-$ & ズ & 10.2 & 8.2 & -2.0 & -0.81 & 11.8 & 10.7 & -1.1 & -0.53 \\
\hline 14 & 味 & 嗊 & 21.6 & 21.0 & -0.6 & -0.18 & 24.2 & 22.1 & -2.1 & -0.89 \\
\hline 15 & 大豆製 & 品 & 129.8 & 122.6 & -7.2 & -0.41 & 112.8 & 103. 4 & -9.4 & -0.50 \\
\hline 16 & その他の & 豆 & 4. 7 & 2.8 & -1.9 & -0.56 & 4. 0 & 10.8 & 6.9 & $0.29 *$ \\
\hline 17 & 果 & 実 & 356.8 & 360.9 & 4. 0 & 0.08 & 400.4 & 345.5 & -54.8 & -1.71 \\
\hline 18 & 緑黄色野 & 菜 & 109.6 & 148. 3 & 38.7 & 2. $26^{*}$ & 115.2 & 105.4 & -9.7 & -0.88 \\
\hline 19 & その他の野 & 菜 & 443.4 & 387.4 & -56.0 & -1.16 & 353.4 & 362.5 & 9.0 & 0.32 \\
\hline 20 & き の & $こ$ & 17.0 & 18.0 & 1. 0 & 0.15 & 11.1 & 17.7 & 6.5 & 1. 48 \\
\hline 21 & 海 & 藻 & 9.3 & 7.4 & -1.9 & -0.63 & 5.4 & 9.1 & 3.8 & 1.21 \\
\hline 22 & 漬 & 物 & 34.3 & 20.3 & -14.0 & $-2.33^{*}$ & 44.2 & 22.8 & -21.4 & $-2.75^{* *}$ \\
\hline 23 & 生 & 魚 & 94.3 & 102.7 & 8.4 & 0.63 & 101.3 & 101.6 & 0.2 & 0.02 \\
\hline 24 & 塩 & 魚 & 15.8 & 7.0 & -8.8 & -1.50 & 31.5 & 25.2 & -6.3 & -0.95 \\
\hline 25 & 魚 加 工 & 品 & 38.0 & 19.4 & -18.6 & -1.83 & 22.1 & 22.7 & 0.6 & 0.07 \\
\hline 26 & 生 & 肉 & 90.2 & 97.7 & 7.5 & 0.57 & 101.5 & 128.5 & 27.1 & 1. 27 \\
\hline 27 & 肉 加工 & 品 & 33.6 & 21.2 & -12.4 & -1.21 & 23.9 & 26.0 & 2.1 & 0.37 \\
\hline 28 & 卵 & & 70.2 & 90.2 & 19.9 & 1.97 & 70.5 & 67.3 & -3.2 & -0.43 \\
\hline 29 & 4 & 乳 & 180.0 & 206.3 & 26.2 & 0.93 & 189.8 & 253.9 & 64.1 & -2.15 \\
\hline 30 & 乳 & 品 & 15. 7 & 10.7 & -5.0 & -0.93 & 13.5 & 18. 4 & 4.9 & 1.09 \\
\hline 31 & しょう & $ゆ$ & 43.7 & 35.4 & -8.3 & $-2.55^{*}$ & 35.9 & 31.0 & -4.8 & $-2.16^{*}$ \\
\hline 32 & 塩 & & 3.22 & 3.97 & 0.75 & 1. 61 & 3.08 & 3. 10 & 0.02 & 0.05 \\
\hline 33 & その他の調味米 & & 15. 6 & 18.1 & 2.6 & 0.71 & 17.0 & 16.1 & -0.9 & -0.31 \\
\hline 34 & 加 工 食 占 & 品 & 0.0 & 6.3 & 6.3 & 99. $00 * * *$ & * 18.9 & 2.6 & -16.3 & $-2.37^{*}$ \\
\hline 35 & その他嗜好飲米 & & 42.1 & 42.8 & 0.7 & 0.03 & 83.5 & 70.0 & -13.5 & -0.54 \\
\hline 36 & そ の 代 & 他 & 5.8 & 7.6 & 1.8 & 0.75 & 7. 3 & 7.8 & 0.5 & 0.17 \\
\hline & $\begin{array}{l}\text { E) 治療し, 服 } \\
\text { 治療なし, } \\
*: p<0.05\end{array}$ & $1 \times 2$ & $P$ & & : $p<0$. & & & & & \\
\hline
\end{tabular}


客観的分析のために, 食物攝取状況を調查して, 教室開講前半と後半の変化を検討したものである。食事内 容の記録にも修飾が起きていることを否定しないが，意識調査や質問票調査よりは実際の状態が現われるの で，食品摂取量に注目したものである゙)6)。

食物攝取状況は確かに改善された。それは数少ない食品で，しかも本教室で取り上げなくても高血圧の原因 ないし高血圧予防によいものとしてょく知られている食品7)8 に限られているが，本教室の成果と考えてよい であろう。しかし，その改善された食物攝取状況が定着したかどらかは本研究からはわからない。

本研究を通して，改めて，保健所業務としてどこまで日常生活の中に踏み込むべきかを考壳させられた。そ のように考えたのも日常生活の中にまで立ち入ることが不足していたという反省があるが，一方では特定の人 にだけにかかわるべきではないという見解が根強いためである。

服薬群（受療し，かつ投薬をうけている高血圧患者）と，非服薬群（受療していない人および受療したこと があっても現在服薬していない境界域血圧の人）の比較では，服薬群のほうが教室受講効果があがっていない ことは著者らにとっては意外な結果であった。食生活を改めないほどに自覚的でないことが高血圧症状を進行 させているのか(つまり効果がないことが原因なのか)，あるいは投薬をうけることがそうさせるのか（つま り結果なのか)，いずれであるかは本研究ではわからない。しかし，とにかく服薬群は改善の成果が劣るよう であるから，服薬群向けのカリキュラムを高血圧予防教室とは異なる内容で組み立てるべきではないかと考光 るようになっている。

これらの知見を今後の高血圧予防教室の運営に役立てていきたい。

\section{ま と め}

保健所の業務現場で行われる「教室」の一事例として「高血圧予防教室」を取り上げて，実践的研究を試み た。

教室カリキュラムとしては 1 コース 4 回（2 時間30分/回）のプログラムで，食物拱取状沉調査を前後 2 回 実施した。食事内容の前後の差を検討して，客観的な評価を行った。

1）牛乳は増加し, 米加工品, 漬け物, しょうゆが減少した。

2）高血圧治療薬の服薬群は非服薬群よりも食事改善の効果が低かった。

3）高血圧予防教室のカリキュラムの検討が具体的に論じられた。

本報告は第27回日本栄養改善学会で発表した。

文

献

1) 横浜市衛生局：横浜市循環器検部要項 (1979)

2）横浜市衛生局：横浜市衛生年報（1965１978各年度）

3）金田治也：日本公衛誌，27，388～397（1980）

4) 横浜市衛生局：横捠市高血圧教室等要項 (1982)

5) 豊川裕之, 他 : 神奈川県足柄上郡中井町食生活実態調查報告 1978年度, (1979) ライフ・プランニング ・センター

6) 豊川裕之：生活の中の栄養学, pp. 62〜72 (1982) 大修館書店

7) 秋山房雄, 他 : 高血圧者の栄養指導/厚生省公衆衛生局栄養課編（1976）第一出版

8）菊地亮也：臨床栄養，60，756７61 (1982)

（受付 : 昭和 57 年12月 27 日） 